\title{
Enhancing Science Education Experiences through Garden Explorations: An Inquiry-based Learning Opportunity at the South Carolina Botanical Garden
}

Lisa K. Wagner ${ }^{1}$ and Shelley W. Fones ${ }^{2}$

SUmmary. G arden Explorations, a continuing program at the South Carolina Botanical G arden (SC BG ), C lemson U niversity, promotes science participation among children, families, undergraduates, and teachers. Integrated by themes of Plants and their Partners, Plants and their Environment, and Web of Life, $G$ arden Explorations programs include Summer Science Camps, Family Science Saturdays, and Family and Community $\mathbf{O}$ utreach Programs. In these programs, college students (largely education, horticulture, biology, and recreation majors) have the opportunity to learn about and experience natural science and math in the garden, along with elementary school teachers, parents, and upper-elementary age children. These inquiry-based learning opportunities enhance and expand the education and professional preparation of $\mathrm{Clemson} U$ niversity students who participate in the program. By involving students in intensive hands-on, inquiry-oriented life science and math activities during $\mathbf{G}$ arden Explorations programs, we seek to increase science literacy in our region.

A

s public gardens and informal science education institutions, we have an opportunity to creatively engage visitors of all ages as they experience our gardens. We have a core responsibility at our college and university gardens to serve our students, expand their learning opportunities and support their professional development. The South Carolina Botanical Garden at Clemson U niversity provides a rich array of experiences that support undergraduate and graduate education. These include traditional university botanical garden roles as a teaching and laboratory resource, center for horticulture, turf, and plant ecological research, and a site for professional work experience. SCBG also enjoys broad-based use; a recent accounting of classes that regularly use SC BG listed >34 classes in nine different departments.

Garden Explorations is supported by a grant to the South C arolina Botanical Garden, Clemson U niversity from the $\mathrm{H}$ oward $\mathrm{H}$ ughes M edical I nstitutethrough their Precollege ScienceE ducation I nitiative program. The program has also received support from the South Carolina Commission on H igher Education's Eisenhower program, the American Association of U niversity Women Educational Foundation, and the Clemson U niversity I nnovation Fund. The cost of publishing this paper was defrayed in part by the payment of page charges. U nder postal regulation, this paper therefore must be hereby marked adverti sement solely to indicate this fact.

${ }^{1}$ South Carolina Botanical Garden, 102 Garden Trail, Clemson U niversity, Clemson, South Carolina 29634-0174.

${ }^{2}$ D epartment of C urriculum and Instruction, Box 340708, Clemson U niversity, Clemson, South Carolina 29634-0708. 
SCBG's successful science education program, Garden Explorations, provides another highly beneficial educational experience for undergraduate and graduate students at Clemson U niversity. By involving students in intensive hands-on, inquiry-oriented life science and math activities during Garden Explorations programs, we seek to increase scienceliteracy in children and adults in our region. This article describes the learning opportunities and impacts provided by this program.

Garden Explorations programs include Summer Science $C$ amps, Family Science Saturdays, and Family and Community O utreach Programs. In these programs, college students (largely education, horticulture, biology, and recreation majors) have the opportunity to learn about and experiencenatural science and math in the Garden, along with classroom teachers, parents, and children. During Garden Explorations, undergraduates work in a mentoring relationship with classroom teachers who have a strong interest in inquiry-based learning and using hands-on science methods. In our informal garden setting, ideas and experiences are easily exchanged; all share the excitement and challenges of teaching science to active and curious children.

Summer Science Camp, the most comprehensive Garden Explorations program, offers upper-elementary age girls a 2-week, half-day science experience in the Garden. Between 35 to 50 girls generally register for the camp, which has taken place for the last four summers. A 3-week summer session course, offered as H ort 400 (I nquiry-based Science) and as a professional development workshop for teachers, accompanies Summer Science C amp. The summer course program provides an opportunity for up to 16 college students and classroom teachers to experience inquiry-based science and math as facilitators. Course participants have the opportunity to practice inquiry-based teaching skills and honetheir techniquesduring camp, which provides vital practicum and professional development experience. M ost of the examples described in this paper are drawn from Summer Science C amp experiences, but are also characteristic of the other programs.

The Family Science Saturdays program serves children (ages 9 to 12) and family members or adult friends, with undergraduates and elementary school teachers working with the families. Professional development workshops for teachers and university students accompany each of these programs, as well.

Family and Community $\mathrm{O}$ utreach programs take place at libraries, schools, and special events, such as Eco-Day at a local energy provider or the Southeastern Flower Show. This programs are tailored to individual site resources.

Garden Explorations activities take advantage of SCBG's 270 acres (110 ha), including the4-acre(2-ha) Wildflower $M$ eadow and adjoining Butterfly Garden, Woodland WildflowerT rail, and extensivestream, pond, and forest areas. In addition, SC BG's excellent greenhouse and plant propagation facilities, with a large greenhouse designated specifically for teaching, provide ample space for greenhouse investigations.

Three themes integrate all Garden Explorations programs:

Plants and their Partners: exploring plant-animal interactions, discovering flower and insect diversity, investigating pollinatorflower relationships, and exploring the life cycles of butterflies and other insects.

Plants and their Environment: discovering plant habitat adaptations and what factors affect growth and reproduction.

WeB OF LIFE: investigating pond, stream, and forest ecology by following the path of a raindrop and finding out what plants and animals live along the way.

SCBG uses a variety of hands-on activities to incorporate science inquiry, writing, art, and music during Garden Explorations programs. We adapted lessons from welldesigned existing curricula, using activities from The Life Cycle of Butterflies [ $\mathrm{N}$ ational Science Resources Center (N SRC), 1992a] and Experimentswith Plants (N SRC, 1992b), as well as from The Growing Classroom: Garden-based Science (J affe and Appel, 1990), GrowLab: Activities for Growing $M$ inds (Pranisand C ohen, 1990), and $H$ ands$\mathrm{O} n \mathrm{~N}$ ature: Exploring the Environment with Children (L ingelbach, 1986).

Inquiry-oriented techniques encourage participants (college students, practicing teachers, and children) to see and discover for themselves. Children and adults quickly became absorbed in investigating, observing, and sharing their discoveries. Brainstorming sessions and group discussions stimulated active exploration of ideas, both during presession workshopsand sessions. For example, participants wrote mock advertisements to invite bees, butterflies, and hummingbirds to visit flowers and shared them with the rest of the group (Pranisand Cohen, 1990). Thisset the stage for a lively field investigation of how frequently pollinators visited different kinds of flowers.

Inquiry-based teaching effectively engages participants in science; for example, one of our education majors commented during a workshop discussion that "I hadn't thought that there were any differences in flower visitors before- or that it (flower visi- 
tation) was even interesting." If we had simply presented him with information and handouts about what he would see in the meadow, we suggest that he would not have been as enthusiastic as he was after discovering pollinator activity in the meadow for himself (personal report).

Spending time in SCBG's varied habitats (including perennial display gardens, pond and shore, stream bottoms, hardwood forest, and wildflower meadows) promotes interest in the plant and animal inhabitants, expanding content knowledge. For example, investigation of pollinators visiting flowersprovided direct experiencewith a wide array of flower visitors, especially insects. In their science methods course, education majors investigate the mouthparts of some insects [Activities Integrating $M$ ath, Science, and Technology (AIM S) education foundation, 1989], but they seldom see them eating. D uring Garden Explorations, students of all ages are able to observe the unfurled proboscis of a butterfly drinking nectar and the very efficient jaws of a caterpillar devouring leaves.

Similarly, the experience of meeting two juvenile barred owls perching above the woodland path can make much more of an impact than a classroom lecture about the quietness of owl wings. O bserving a feathered raptor with outstretched talons flying toward them furthered their understanding of this concept. And while most adults and children knew that turtles lay eggs, watching a female eastern box turtle (Terrapenecarolina L.) dig a hole and carefully deposit five leathery eggs was an extraordinary moment. These experiences will inspire storiesand continued investigationsto be shared with inquisitive students (young and old) in the future, as well as encourage continuing learning.

Carrying out student-driven investigations is a vital component of Garden Explorations. Investigating sizes, shapesand colors of diverse seeds led to questions related to seed germination. Students formulated hypotheses and brainstormed ways to test them ( $\mathrm{N}$ ational Science Resources Center, 1992b). U ndergraduate facilitatorshelped thestudentscomplete their designs and carry them out. It wasthe undergraduates' responsibility to ensure that the elementary students understood the concept of investigat- ing one variable at a time and controlling other factors. Seedswere placed in black envelopes, on windowsills, in the refrigerator and even in supply tubs. As seeds began to germinate, facilitators prompted students to observe closely, make predictions, identify changes, record data and use other scientific process skills encouraged by the $\mathrm{N}$ ational Science $\mathrm{E}$ ducation Standards (National Research Council, 1996).

While following a raindrop through SCBG, groups of children and facilitators identified areas where erosion had occurred and discussed ways to reduce it. To determine which surface absorbed the most water and reduced runoff ( affeand Appel, 1990), they investigated how turf, bare soil, sand, mulch, and other substrates affected water quality and quantity. Students and facilitators designed investigations to address specific questions. Facilitators guided group experiments and observed the outcomes, encouraging students to draw in-depth conclusions. Being able to assist the girls and respond to their questions, knowing that their mentors were readily available, gave the undergraduates opportunities to clarify their own understandings and teach investigative lessons without feeling isolated.

$O$ ne aspect of the $G$ arden Explorations Summer Science Camp that fascinated children and adults alike wastheraising of painted lady (Vanessa cardui L.) butterflies ( $\mathrm{N}$ ational Science Resources Center, 1992b) during the Plants and their Partners segment. Starting with bluish eggs, barely visible on the leaves of the mallow plants, tiny caterpillarsemerged aseggs changed in color. Pipe cleaners and paintbrushes served to gently transfer caterpillars to the prepared food medium. The girls recorded their observations daily and noted when the caterpillars attached themselves to the tops of the containers in a J shape. O nce the formation of chrysalides was complete, thestudentscarefully pinned them to the butterfly house netting. They checked frequently to see newly emerged painted lady adults drinking sugar water. Before long, they were able to observenew bluish eggslaid on green leaves, completing the life cycle.

\section{Impacts}

$\mathrm{H}$ aving butterfly houses in the classroom made observing all stages of development easily accessible. D uring transitions from one activity to another, studentsand facilitators spent as much time as possible watching the insects and observing their behavior. Additional observations in SCBG's 4acreW ildflower $M$ eadow, at its peak in June, compounded their learning. After spending time simply watching pollinator activity in the meadow, Garden Explorations participants quickly became absorbed in generating "I wonder" questions, comparing butterfly and bumblebee visitsto different flowers, observing differencesin flower color and shape, and checking for nectar presence.

Early in a typical science curriculum, elementary students are introduced to the concepts of ecosystems, food chains and webs. But how often do examples come from observations conducted in person? E ach day during summer science camp, students recorded the organisms they observed and made note of where they were seen. Toward the end of the second week, the groups created food webs (J affe and Appel, 1990) based on inhabitants of SCBG. They started simply, but rapidly created complex food webs based on their observations. O ne group became so engrossed in developing their food web that they missed the closing poetry and song that ended each day of camp. What better impetus for future educators to use inquirybased science than to facilitate alesson that children love so much they want to continue beyond the end of the activity?

Learning experiences extended beyond the bounds of traditional science knowledge and incorporated the concept of multiple intelligences (Armstrong, 1993, 1994; Campbell, et al., 1996). Adults and children were encouraged to learn through recording in journals, drawings, flower and caterpillar models, songs and writing. When student work was shared with other groups and parents on the final day, individual learning styles were evident. Some children less prone to excel in atypical verbal-linguistic, logical-mathematical classroom shone when it came to performing and working with their hands. Observing the spectrum of learning modes was perhaps the best means of encouraging educators to embrace teaching with a variety of approaches.

Actively working with children 
and their families throughout the year in Family Science Saturdays and Summer Science Camp provides opportunitiesbeyond the traditional education program for undergraduates. N ot only do their experiences include informal teaching and mentoring, but also they demonstrate the value of hands-on activities that are relevant to thelives of children of many ability levels and socioeconomic groups. In addition, life scienceinformation comesalive as they observe the interactions of plants and animals at SCBG. Joint exploration of new discoveries made learning a cooperative experience. $M$ utual enjoyment of the activities was strong reinforcement for continued science investigations by both girls and adults. The multilayered aspects of the program allow them to be teachers and facilitators, while also being students who are discovering the importance of lifelong learning.

Education majors have opportunitiesduring their practica and student teaching experiences to work with children, but thesetend to bemorelimited in scope than the experiences offered in Garden Explorations. Working in SCBG in an informal relationship is quite a different experience. Facilitators and children learn together; children and adults became thoroughly engrossed in investigating flower structure, tracking flower visitors in the Butterfly $\mathrm{G}$ arden, following growth of caterpillars, and searching for aquatic insect larvaealong SCBG'sstream. And even when the adults know the answers, they discover that encouraging the students to find answers for themselves reaps many rewards. Children find they are able to ask a wide variety of questionsand then, with adult facilitation, are able to use reference materials effectively to answer these questions. Certainly with the explosion of science discoveries and new information, knowing how to find the answer ismorevaluablethan memorizing facts, and lies at the heart of improving science education.

U ndergraduates in other majors at C lemson rarely have structured opportunities to work with children in an informal education setting. We have found these experiences can have a profound effect on the potential future careers of students who participate, especially among science majors who become interested in education careers (both formal and informal), based on self-reports.

Adult participants reported an increased confidence in using inquirybased, hands-on materialsfor teaching science concepts, resulting in the use and dissemination of these activities. Joint exploration of new discoveries made learning a cooperative experience. $M$ utual enjoyment of the activities was strong reinforcement for continued science investigations by both children and adults. O ne of the education majors who participated in $\mathrm{Gar}$ den Explorations became quite adept at facilitating science inquiry and using interactive activities to enhance the teaching of concepts and processes. Thisyear, hewasnominated as Rookie of the Year in the school district where he teaches mathematics to inner city children.

The results of our program have been very encouraging and support the effectiveness of using an inquirybased approach to enhance science and mathematicslearning. Assessment and evaluation surveys reflect the significance of these experiences in encouraging student, teacher, and adult interest in science.

For collegestudents of any major, often used to being passive recipients of knowledge, involvement in learning through an inquiry-based format can be energizing. Furthermore, using inquiry can expand their awareness of improved learning and teaching practices.

Our basic approach in Garden
Explorations encourages close examination of the natural world, promoting open exploration of ideas and "I wonder" questions, allowing ample time for investigation, and resulting in authentic science discovery. $O$ ur experienceswith $\mathrm{G}$ arden Explorations have underscored the effectiveness of this approach in promoting interest and participation in science among families, children, teachers, and preservice teachers.

\section{Literature cited}

Activities Integrating $M$ ath, Science, and Technology. 1989. Table manners. Critters. AIMS Educ. Foundation, Fresno, Calif.

Armstrong, T . 1993. Seven kinds of smart. Plume/ Penguin, N ew York.

Armstrong, T. 1994. M ultipleintelligences in the classroom. Assn. Supervision C urric. Dev., Alexandria, $\mathrm{Va}$.

Campbell, L., B. Campbell, and D. Dickinson. 1996. Teaching and learning through multiple intelligences. Allyn and Bacon, $\mathrm{N}$ eedham $\mathrm{H}$ eights, $\mathrm{M}$ ass.

J affe, R. and G. Appel. 1990. The growing classroom: $\mathrm{G}$ arden-based science. AddisonWesley. M enlo Park, Calif.

Lingelbach, J. (ed.). 1986. H ands-on nature: I nformation and activities for exploring the environment with children. Vt. Inst. N atural Sci., Woodstock, Vt.

N ational Research Council. 1996. N ational science education standards. $\mathrm{N}$ atl. A cad. Press, Washington, D.C.

$N$ ational Science R eso urcesC enter. 1992a. The life cycle of a butterfly. Teacher's guide. $\mathrm{N}$ atl. Sci. R esources Ctr., Washington, D.C.

$\mathrm{N}$ ational Science Reso urcesC enter. 1992b. Experiments with plants. T eacher's guide. $\mathrm{N}$ atl. Sci. ResourcesC tr., Washington, D.C.

Pranis, E. and J. Cohen. 1990. Grow L ab: Activities for $G$ rowing $M$ inds. . N atl. Gardening Assn., Burlington, $\mathrm{Vt}$. 